\title{
Sustainable Development and Sustainability Management in the European Union Countries
}

\author{
Emilia Huttmanová*
}

\begin{abstract}
The terms sustainable development and sustainability are now used in many areas and spheres of life and become a modern phenomenon in determining the direction of progress. Sustainability is the goal of many strategic documents and should be implemented in economic and social life. The attractiveness of the terms sustainability and sustainable development leads to high frequency of their use, and is also evidence of their multidisciplinary meaning. The aim of this paper is to evaluate the management of sustainable development in the countries of the European Union through selected indicators characterizing sustainable development and its main dimensions. The paper presents the results of the evaluation of sustainable development using selected methods and indicators.
\end{abstract}

Key words: Sustainability, Management of Sustainability, Sustainable Development, Indicators, Quantification

\section{Introduction}

Sustainable development is a general and fundamental objective of the European Union aimed at continuous improvement of the quality of life and the wellbeing of present and future generations based on interconnections among economic development, environmental protection and social justice. The aim of the European Union, which is referred to in the Monitoring Report on 2011 Review of the European Union's Sustainable Development Strategy ${ }^{1}$, is to achieve continuous improvement of the quality of life of the population through sustainable communities that control and use resources efficiently and acquire ecological and social innovation potential of the economy to ensure prosperity, protection of the environment and social cohesion.

\section{Theoretical Foundations of Sustainable Development}

Moldan (2009, p. 88) comprehensibly deals with the historical context of sustainable development and the need for environmental protection improvement, and states that care for natural resources and the environment is a natural part of life from the beginnings of mankind. The United Nations (1983) also tried to solve the contradictions between economic growth and the destruction of natural resources base.

The European Union also considers the issues of sustainability and sustainable

\footnotetext{
${ }^{1}$ Retrieved from: http://ec.europa.eu/eurostat/documents/3217494/5732101/224-SK-SK.PDF [2014-05-03]
} 
development as crucial and essential for the further development of the European area. Also for this reason, the European Parliament defined sustainable development as the improvement of living standards and well-being of people within the limits of the capacity of the ecosystems while keeping natural wealth and biodiversity for the present and future generations. Sustainable development is explained, or normatively defined, as a balance among so-called pillars of sustainable development: ecological, social and economic, sometimes completed also with the fourth, cultural pillar, and another pillar, i.e. a good public administration. The system of three pillars is possible to derive from the fulfilment of the condition of the basic definition of sustainable development according to Brundtland, who considers the pursuit of human needs to be the purpose of sustainable development.

Individual views of sustainability more or less overlap, that is why it is difficult to choose the "right" definition. Sustainability is multidimensional, not static and as to the content, constantly evolving concept (Huttmanová, 2015).

Sustainability and sustainable development is also dealt with by Demo, Hronec, Tóthová et al., 2007; Maier, 2012; Jeníček, 2010 and others.

\section{The Aim of the Paper and the Methods Used}

The aim of this paper is to evaluate the management of sustainable development in the European Union countries through selected indicators characterizing sustainable development and its main dimensions.

Monitoring of territorial changes and of the efficiency of policies and measures for the promotion of sustainable development is a fundamental part of the management of sustainable development. By watching the intensity of economic, social and environmental phenomena in different parts of the territory and by monitoring and evaluation of the changes of physical elements in the territory, it is possible to help considerably to provide the knowledge and understanding of ongoing changes, their nature and causes. In the paper, selected indicators of sustainable development (according to EUROSTAT) are used for the evaluation of sustainable development. Analysed data were processed for the year 2014; in two cases (Greenhouse gas emissions and $\mathrm{CO}_{2}$ emissions) for the last period available for all the evaluated countries.

For the realization of the evaluation by the cluster analysis, we chose nine headline indicators of sustainable development representing given themes (Table 1).

Table 1 Themes and selected indicators of sustainable development

\begin{tabular}{|l|l|}
\hline Theme & Indicator \\
\hline $\begin{array}{l}\text { Socio-economic } \\
\text { development }\end{array}$ & Real GDP per capita \\
\hline $\begin{array}{l}\text { Sustainable } \\
\text { consumption } \\
\text { production }\end{array}$ & Resource productivity \\
\hline Social inclusion & Persons at-risk-of-poverty or social exclusion \\
\hline Public health & Healthy life years and life expectancy at birth - females \\
\cline { 2 - 2 } & Healthy life years and life expectancy at birth - males \\
\hline
\end{tabular}




\begin{tabular}{|l|l|}
\hline $\begin{array}{l}\text { Climate change and } \\
\text { energy }\end{array}$ & Primary energy consumption \\
\hline Sustainable transport & Energy consumption of transport relative to GDP \\
\cline { 2 - 2 } & Greenhouse gas emissions by transport mode \\
\hline Global partnership & $\mathrm{CO}_{2}$ emissions per inhabitant in the EU and in developing countries \\
\hline
\end{tabular}

(Source: Eurostat; http://ec.europa.eu/eurostat/web/sdi/indicators)

The data were processed with the help of a statistical software Statistica 12. Evaluation is realized by the method of cluster analysis. From among various methods of cluster analysis, we applied hierarchical cluster methods resulting, in graphic representation, in a tree diagram called dendrogram. For the measurement of distance among individual points, Euclidean distance and the method of the nearest neighbour, which are the most frequently applied in cluster analyses, were used.

Euclidean distance is computed as follows:

$$
d_{i j}=\sqrt{\sum_{k=1}^{n}\left(x_{i k}-x_{j k}\right)^{2}}
$$

When creating dendrogram, we assessed the level of faithfulness. The cophenetic correlation coefficient and criterion $\Delta$ (delta coefficient) are the characteristics of the evaluation of the quality of dendrogram. Cophenetic correlation coefficient CC is a Pearson's correlation coefficient of real and dendrogram's predicted distance:

$$
C=C \frac{\left.\sum_{i<j}\left(x_{j}\right)-x\right)_{j}(-t)}{\sqrt{\sum_{i<j}\left(x_{j}\right)-x^{2} \sum_{i<j}\left(t_{j},-t^{2}\right)}} \text {, }
$$

Where:

$x_{(i, j)}$ - original Euclidean distance between observations $i$ and $j$

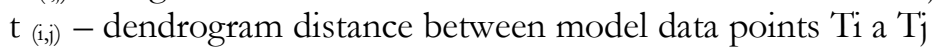

In general, it is valid that the higher the value of CC, the higher the faithfulness and better cluster model it is. We accepted model where value of CC $\geq 0,75^{2}$.

Second criterion quantifying the quality of clusters by the completeness of linkage is delta $\Delta$ :

\footnotetext{
${ }^{2}$ MELOUN, Milan, Jiř́ MILITKÝ a Martin HILL, 2005. Počitačová analýza vícerozumérných dat v príkladech. Praha : Academia, ISBN 80-200-1335-0.
} 
$\Delta_{A}=\left[\frac{\sum_{i<j}^{N}\left|d_{i j}-d_{i j}^{*}\right|^{1 / A}}{\sum_{i<j}^{N}\left(d_{i j}^{*}\right)^{1 / A}}\right]^{A}$

Where:

$\mathrm{d}_{\mathrm{ij}}$ - distance in original distance matrix

$\mathrm{d}_{\mathrm{ij}}{ }^{*}$ - distance obtained from the dendrogram

$\mathrm{A}=0,5$ or 1

For the quality of acquired clusters, it is required that the value of $\Delta_{\mathrm{A}}$ is close to zero.

\section{Results and Discussion}

We observe the measure of similarity based on selected indicators of sustainable development in 28 European Union countries. We monitor this similarity of individual countries in the context of headline themes of sustainable development and corresponding indicators. We present the observed values of individual indicators in the EU countries in Table 2.

Table 2: Values of Individual Indicators of Sustainable Development in the EU countries

\begin{tabular}{|c|c|c|c|c|c|c|c|c|c|}
\hline & Indicat & & & & & & & & \\
\hline \multirow[t]{2}{*}{ EU Country } & 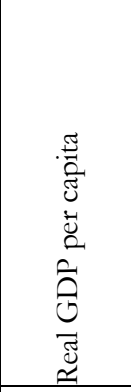 & 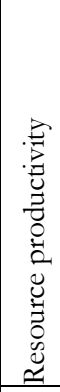 & 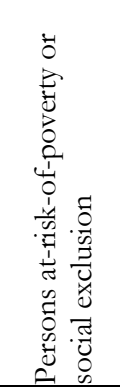 & 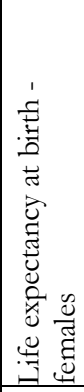 & 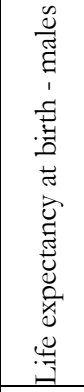 & 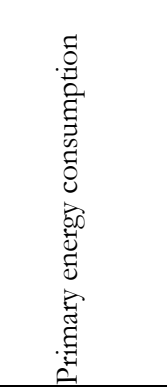 & 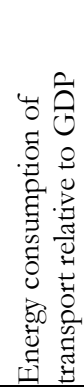 & 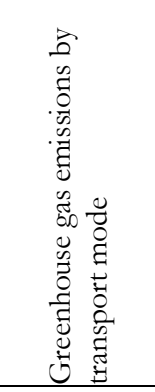 & 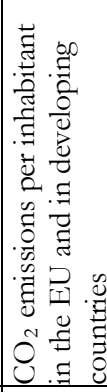 \\
\hline & $\begin{array}{l}€ \text { per } \\
\text { capita }\end{array}$ & $\begin{array}{l}€ \\
\text { per } \\
\text { kg }\end{array}$ & $\begin{array}{lr}1 & 000 \\
\text { persons }\end{array}$ & years & years & $\begin{array}{l}\text { million } \\
\text { TOE } \\
\text { (tonnes of } \\
\text { oil } \\
\text { equivalent) }\end{array}$ & $\begin{array}{l}\% ; \\
\text { index } \\
100 \\
= \\
\text { year } \\
2000\end{array}$ & $\begin{array}{l}\text { million } \\
\text { tonnes of } \\
\mathrm{CO}_{2} \\
\text { equivalent }\end{array}$ & tonnes \\
\hline Belgium & 33800,0 & 2,4 & 2339,0 & 83,9 & 78,8 & 45,0 & 92,2 & 24,7 & 9,1 \\
\hline Bulgaria & 5500,0 & 0,3 & 2909,0 & 78,0 & 71,1 & 17,2 & 103,7 & 7,4 & 6,6 \\
\hline $\begin{array}{l}\text { Czech } \\
\text { Republic }\end{array}$ & 15200,0 & 1,0 & 1532,0 & 82,0 & 75,8 & 38,6 & 97,5 & 16,6 & 10,6 \\
\hline
\end{tabular}




\begin{tabular}{|c|c|c|c|c|c|c|c|c|c|}
\hline Denmark & 43700,0 & 2,2 & 1007,0 & 82,8 & 78,7 & 16,7 & 93,0 & 11,9 & 7,1 \\
\hline Germany & 33800,0 & 2,1 & 16508,0 & 83,6 & 78,7 & 291,8 & 97,9 & 159,3 & 10,0 \\
\hline Estonia & 13200,0 & 0,5 & 338,0 & 81,9 & 72,4 & 6,6 & 84,0 & 2,2 & 12,9 \\
\hline Ireland & 39500,0 & 1,8 & 1274,0 & 83,5 & 79,3 & 13,4 & 86,6 & 11,1 & 8,3 \\
\hline Greece & 17000,0 & 1,4 & 3885,0 & 84,1 & 78,9 & 23,7 & 95,4 & 17,9 & 8,2 \\
\hline Spain & 22400,0 & 2,7 & 13402,0 & 86,2 & 80,4 & 112,6 & 89,5 & 79,4 & 5,9 \\
\hline France & 31200,0 & 2,6 & 11540,0 & 86,0 & 79,5 & 234,5 & 96,4 & 131,7 & 5,7 \\
\hline Croatia & 10200,0 & 1,1 & 1243,0 & 81,0 & 74,7 & 7,7 & 101,3 & 5,7 & 4,5 \\
\hline Italy & 25300,0 & 3,1 & 17146,0 & 85,6 & 80,7 & 143,8 & 100,4 & 103,4 & 6,5 \\
\hline Cyprus & 20100,0 & 1,6 & 234,0 & 84,7 & 80,9 & 2,2 & 89,4 & 1,9 & 8,2 \\
\hline Latvia & 10400,0 & 0,5 & 645,0 & 79,4 & 69,1 & 4,4 & 78,2 & 2,8 & 3,6 \\
\hline Lithuania & 11200,0 & 0,8 & 804,0 & 80,1 & 69,2 & 5,6 & 95,8 & 4,6 & 4,7 \\
\hline Luxembourg & 78200,0 & 3,8 & 96,0 & 85,2 & 79,4 & 4,2 & 86,6 & 6,3 & 20,7 \\
\hline Hungary & 10500,0 & 0,9 & 3097,0 & 79,4 & 72,3 & 20,7 & 88,9 & 10,1 & 4,6 \\
\hline Malta & 17500,0 & 1,4 & 99,0 & 84,2 & 79,8 & 0,9 & 92,7 & 0,5 & 6,7 \\
\hline Netherlands & 37900,0 & 3,7 & 2751,0 & 83,5 & 80,0 & 62,7 & 91,1 & 35,6 & 9,9 \\
\hline Austria & 36000,0 & 1,7 & 1609,0 & 84,0 & 79,2 & 30,6 & 96,2 & 22,8 & 8,1 \\
\hline Poland & 10500,0 & 0,6 & 9337,0 & 81,7 & 73,7 & 89,1 & 82,9 & 44,0 & 8,4 \\
\hline Portugal & 16300,0 & 1,1 & 2863,0 & 84,4 & 78,0 & 20,7 & 94,3 & 15,5 & 4,8 \\
\hline Romania & 6900,0 & 0,3 & 8397,0 & 78,7 & 71,4 & 30,8 & 98,5 & 15,1 & 4,2 \\
\hline Slovenia & 17600,0 & 1,3 & 410,0 & 84,1 & 78,2 & 6,5 & 101,1 & 5,5 & 7,6 \\
\hline Slovakia & 13500,0 & 1,1 & 960,0 & 80,5 & 73,3 & 15,3 & 77,4 & 6,8 & 6,5 \\
\hline Finland & 34100,0 & 1,1 & 927,0 & 84,1 & 78,4 & 33,4 & 98,4 & 12,1 & 9,4 \\
\hline Sweden & 40300,0 & 1,7 & 1636,0 & 84,2 & 80,4 & 46,2 & 93,6 & 18,5 & 4,8 \\
\hline $\begin{array}{l}\text { United } \\
\text { Kingdom }\end{array}$ & 30400,0 & 3,5 & 15188,0 & 83,2 & 79,5 & 182,4 & 91,6 & 113,8 & 7,6 \\
\hline
\end{tabular}

(Source: Eurostat; http://ec.europa.eu/eurostat/web/sdi/indicators) 
Tree Diagram for 28 cases (EU countries)

Complete Linkeage

Euclidean Distance

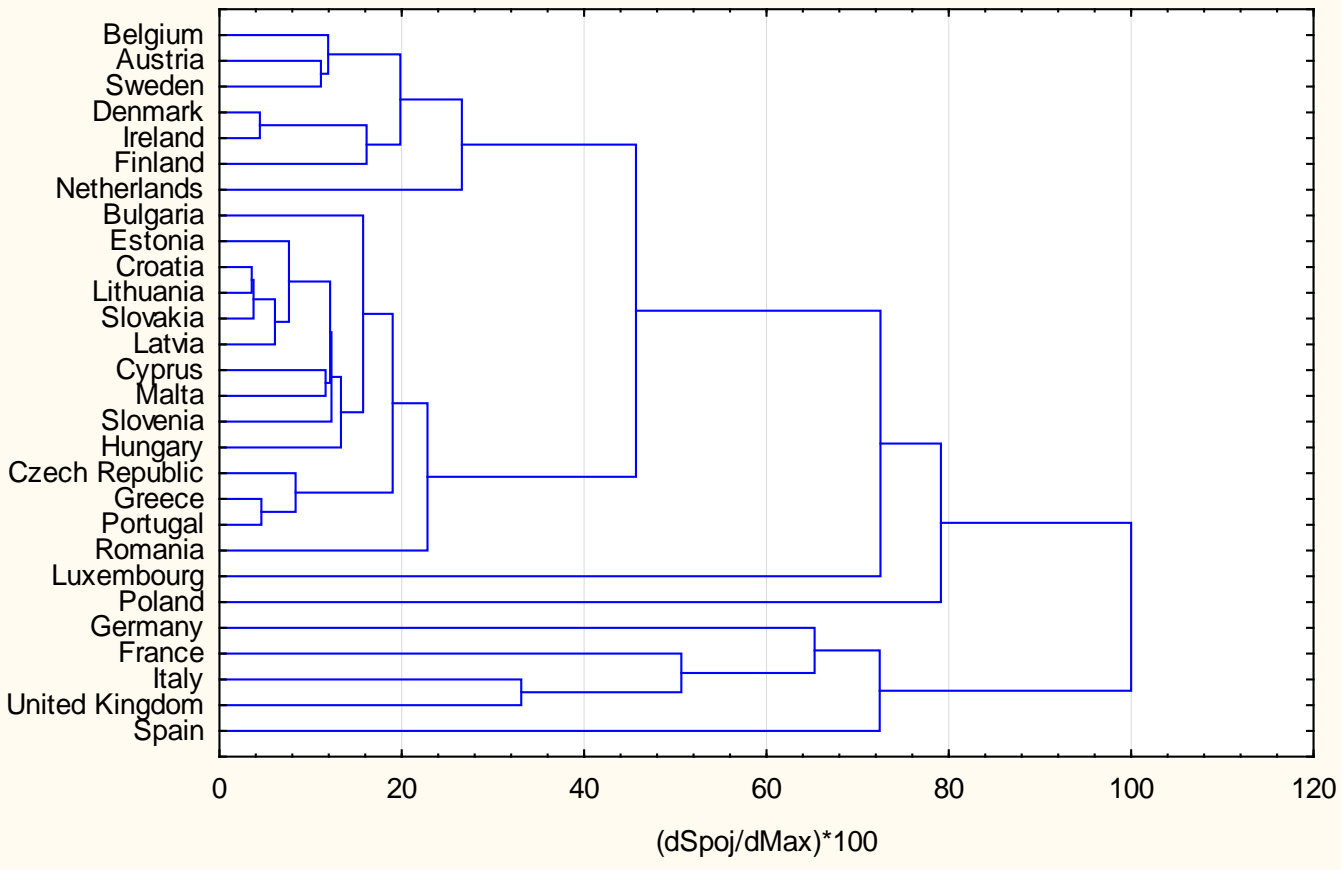

Figure 1: Dendrogram for Selected Indicators of Sustainable Development in the EU Countries

(Source: Own Processing)

Based on the results of the realized cluster analysis depicted in the dendrogram (Fig. 1), it is possible to state that evaluated countries are clustered into two relatively separated clusters:

Cluster is composed of: Germany, France, Italy, United Kingdom and Spain Cluster is composed of: remaining countries, which also create other separated clusters:

2a) Belgium, Austria, Sweden, Denmark, Ireland, Finland, Netherlands

2b) Bulgaria, Estonia, Croatia, Lithuania, Slovakia, Latvia, Cyprus, Malta, Slovenia, Hungary, Czech Republic, Greece, Portugal

2c) Poland

2d) Luxembourg

Poland and Luxembourg are not classified as it is not possible to group them definitely to any of the clusters according to the selected measure of similarity.

Within the second cluster, in multiple clusters, the closest linkage (i.e. the highest measure of similarity) is shown by the following countries:

1) Croatia, Lithuania and Slovakia;

2) Denmark and Ireland;

3) Greece and Portugal.

Slovakia shows the highest measure of similarity in the context of the realized 
cluster analysis with countries Croatia and Lithuania (followed by Latvia and Estonia). These countries are closest to each other in individual evaluated indicators of sustainable development. Based on the realized cluster analysis, it is possible to state that the European Union countries do not create homogeneous group in the field of sustainable development and achievement of sustainability.

\section{Conclusion}

Sustainable development is relatively difficult to quantify. That is why it is complicated to plan, organize and manage the processes in the context of sustainable development at individual levels of economic and social life. Management of sustainable development is focused on finding a new type of healthier and long-term development. It is a set of activities and processes and usage of such tools that aim at securing sustainable development. The aim of sustainability management is to create the right model of economic and environmental performance of economy in such a way as to reach sustainability (Huttmanová, 2015).

Realized analysis and its results create a suitable platform for the comparison of sustainability of development of individual countries and offer possibilities for the identification of the tools which can secure the sustainability of development. This, however, requires further examination. The European Union space also provides a suitable platform for the comparison of these tools, their selection and implementation in the context of a given country.

The countries, which are similar in the field of sustainability of development, were identified by cluster analysis. Based on the results of evaluation of similarity, it is possible to be inspired by more developed countries in the way how they achieved better results and progress in the field of sustainability of development. It is obvious that not all the tools of other economies are suitable to be used in every country, but it is possible to selectively determine and implement some of them in the management of sustainability of development.

\section{Acknowledgement}

Paper is the result of the Project implementation: University Science Park TECHNICOM for Innovation Applications Supported by Knowledge Technology, ITMS: 26220220182, supported by the Research \& Development Operational Programme funded by the ERDF.

The paper is the result of the Project KEGA realization: "KEGA 032PU4/2014 Príprava študijných materiálov preprogram Environmentálny manažment v 1. stupni štúdia a nadväzného študijného programu Environmentálny manažment." 


\section{References}

ADAMIŠIN, Peter a Juraj TEJ, 2012. The analysis of the economic efficiency of regions on the level of nuts III and on the proportion of municipial taxation. In: Polish journal of management studies. Vol. 5 (2012), s. 60-77. ISSN 2081-7452.

ADAMIŠIN, Peter a Roman VAVREK, 2015. Analysis of the links between selected socio-economic indicators and waste management at the regional level in the Slovak republic. In: 5th Central European conference in regional science: conference proceedings. Košice : Technical university of Košice. p. 1 - 9. ISBN 978-80-553-2015-1.Available to internet: http://www3.ekf.tuke.sk/cers/files/zbornik2014/PDF/Adamisin.pdf

BARROW, C.J., 2006. Environmental Management for Sustainable Development. Routledge Taylor \&Francis Group, London, New York, 454 p. ISBN 978-0-415-36534-5.

CHOVANCOVÁ, Jana. 2015. Manažment environmentálmych riz̨ík. Prešov: PU v Prešove. 129 s. ISBN 978-80555-1394-2. Dostupné na: http://www.pulib.sk/web/kniznica/elpub/dokument/Chovancova4

DEMO, Milan, Ondrej HRONEC, Monika TÓTHOVÁ a kol., 2007. Udržatel’ný rozvoj: život v medżiach únosnej kapacity biosféry. Nitra: Slovenská pol’nohospodárska univerzita, ISBN 978-80-8069-826-3.

DUŠEK, Jiř́, Lubomír PÁNA a kol. 2010. Udry̌itelný rozvoj v evropskych regionech. České Budejovice : Vysoká škola evropských a regionálních stúdií, ISBN 978-80-86708-90-4.

HUT'TMANOVÁ, Emília. 2015. Analytický poblad na manažment udrǔatelnosti rožoja krajinní Európskej únie $v$ kontexte globálnych zmien. Habilitačná práca. Prešov: PU v Prešove, $217 \mathrm{~s}$.

JENÍČEK, Vladimír a kol., 2010. Vyvážený rozuoj na globální a regionální úrovni. Praha: Nakladatelství C. H. Beck, ISBN 978-80-7400-195-6.

LAČNÝ, Martin. 2012. Environmentálna, sociálna a ekonomická oblast' spoločenskej zodpovednosti podnikov. In: Folia oecologica 7. Prírodné vedy. Roč. 54, č. 7 (2012), s. 55-65. ISSN 1338-080X.

MAIER, Karel a kol., 2012. Udř̌itelný rozvoj uizemí. Praha: Grada Publishing, ISBN 978-80-247-4198-7.

MELOUN, Milan, Jiři MILITKÝ a Martin HILL, 2005. Počitačová analyza vicerozmèrných dat vpríkladech. Praha:Academia, ISBN 80-200-1335-0.

MOLDAN, Bedřich. 2009. Podmanená planéta. Praha: Univerzita Karlova v Praze, Nakladatelství Karolinum, ISBN 978-80-246-1580-6.

NOVÁČEK, Pavel, 2011. Udry̌itelný rozvoj. Olomouc: Univerzita Palackého, ISBN 978-80-244-2795-9.

PRČÍK, Martin, Marián KOTRLA, 2013. Environmental and socio-economic aspect of growing Miscanthus genotypes. In: Scientific papers. Vol. 13, iss. 1 (2013), s. 201-204. ISSN 2247-3527.

PROKEINOVÂ, Renáta. 2006. Analýza európskych krajín z hladiska trvalo udržatel’ného rozvoja použitím kvantitatívnych metód. In: INTERNATIONAL SCIENTIFIC DAYS 2006 Faculty of Economic and Management SAU in Nitra "Competitivness in the EU - Challenge for the V4 countries". [online] Nitra: SPU, [cit. 2014-04-10]. s. 1449 - 1454. Dostupné na internete: http://www.slpk.sk/eldo/2006/025_06/sekcia7/s7_prokeinova_renata_11.pdf 